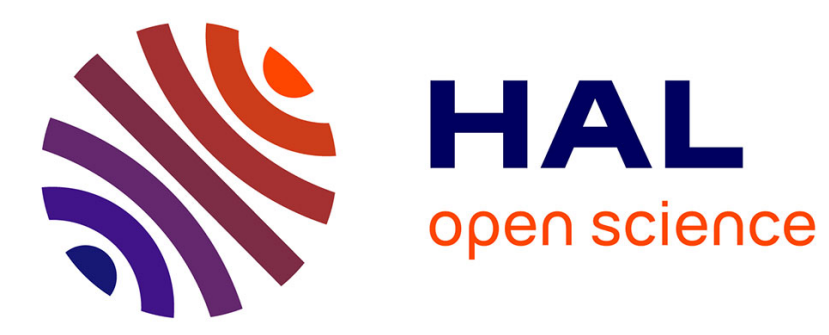

\title{
Fatty acids in Murciano-Granadina goats' milk
}

Pilar Hellin, Maria-Belen Lopez, Maria-José Jordan, José Laencina

\section{To cite this version:}

Pilar Hellin, Maria-Belen Lopez, Maria-José Jordan, José Laencina. Fatty acids in Murciano-

Granadina goats' milk. Le Lait, 1998, 78 (3), pp.363-369. hal-00929601

\section{HAL Id: hal-00929601 \\ https://hal.science/hal-00929601}

Submitted on 1 Jan 1998

HAL is a multi-disciplinary open access archive for the deposit and dissemination of scientific research documents, whether they are published or not. The documents may come from teaching and research institutions in France or abroad, or from public or private research centers.
L'archive ouverte pluridisciplinaire HAL, est destinée au dépôt et à la diffusion de documents scientifiques de niveau recherche, publiés ou non, émanant des établissements d'enseignement et de recherche français ou étrangers, des laboratoires publics ou privés. 


\title{
Fatty acids in Murciano-Granadina goats' milk
}

\author{
Pilar Hellín*, María-Belen López, Maria-José Jordán, \\ José Laencina
}

Food Technology, Veterinary Faculty, University of Murcia, 30071 Murcia, Spain

(Received 13 November 1996; accepted 31 October 1997)

\begin{abstract}
The objective of this study is to identify the principal fatty acids in MurcianoGranadina goats' milk. The technique used to identify and quantify these acids was gas chromatography through flame ionization and mass spectrometry. The principal fatty acids found were butyric acid $(3.0 \%)$, caproic acid $(6.3 \%)$, caprylic acid $(2.5 \%)$, capric acid $(10.4 \%)$, lauric acid $(5.6 \%)$, myristic acid $(12.8 \%)$, palmitic acid $(34.8 \%)$, stearic acid $(6.8 \%)$, oleic acid $(13.3 \%)$, linoleic acid $(3.6 \%)$ and linolenic acid $(0.9 \%)$. Using the results obtained, a descriptive statistical study was undertaken. The relationship between fatty acids was determined using Pearson's correlation matrix, and highly significant negative statistical correlations were found between palmitic acid and the other fatty acids studied, although no significant correlations were found between the quantity of fat present in the milk and the values of fatty acids. () Inra/Elsevier, Paris.
\end{abstract}

\section{goat milk / fat / fatty acid / gas chromatography}

Résumé - Les acides gras dans le lait de chèvre murciano-granadina. L'objectif de ce travail est la quantification des acides gras majeurs dans le lait de chèvre murciano-granadina. La technique d'identification de ceux-ci a été la chromatographie en phase gazeuse avec ionisation de flamme et la spectrométrie de masse. Les acides gras majeurs déterminés sont les acides butyrique $(3,0 \%)$, caproïque $(6,3 \%)$, caprylique $(2,5 \%)$, caprique $(10,4 \%)$, laurique $(5,6 \%)$, myristique $(12,8 \%)$, palmitique $(34,8 \%)$, stéarique $(6,8 \%)$, oléique $(13,3 \%)$, linoléique $(3,6 \%)$ et linolénique $(0,9 \%)$. Les acides palmitique $(34,8 \%)$, myristique $(12,8 \%)$ et oléique $(13,3 \%)$ présentent les pourcentages les plus élevés. À partir des résultats obtenus, une étude statistique descriptive a été réalisée. Les relations des acides gras entre eux et avec le pourcentage de matière grasse dans les échantillons ont été déterminées à travers la matrice de corrélation de Pearson. Des corrélations négatives significatives ont été trouvées entre l'acide palmitique et les autres acides gras étudiés, mais il n'y a pas de corrélations significatives entre la quantité de matière grasse du lait et les proportions individuelles des acides gras. (C) Inra/Elsevier, Paris.

lait de chèvre / matière grasse / acide gras / chromatographie gazeuse

* Correspondence and reprints. 


\section{INTRODUCTION}

In recent years production of MurcianoGranadina goats' milk has increased significantly. This makes it interesting to study the nutritive and organoleptic qualities of the milk and related dairy products, with special emphasis on the production of cheese as a derived product. Variations in the fatty acid content give rise to changes in the organoleptic and nutritional qualities of the products derived from the milk, and these changes in turn have a marked influence on spontaneous oxidation reactions which occur in these products, reducing their quality and organoleptic properties.

One of the principal steps in characterizing milk production is to establish the fatty acid profile. This determination makes it possible to establish the influence of these compounds on the final properties of the cheese, especially in the flavor. The principal fatty acids present in goats' milk are the same as in cows' and ewes' milks: butyric, caproic, caprylic, capric, lauric, myristic, palmitic, stearic, oleic, linoleic and linolenic acid. The main feature of goats' milk is the high content of short-chain fatty acids as opposed to the $12 \%$ present in cows' milk [19], a property which can be exploited to differentiate mixtures of milk from different origins.

The influence of genetic conditions in the fatty acid profile [20] justifies the study of a group of animals in order to be able to define a general profile. The objective of the study is to determine the profile of the principal fatty acids in the milk of Murciano-Granadina goats and to study the statistical relationships between them.

\section{MATERIALS AND METHODS}

\subsection{Milk}

Thirty-nine samples of goats' milk from the Murciano-Granadina breed were studied, all from the experimental farm run by the Consejería de Agricultura, Medio Ambiente y Agua of the Región of Murcia. The samples were collected during the month of June, in the middle of the lactation curve. The criteria for selecting the animals used in the study were the following: animals in second or third lactation, minimum milk yield of $0.5 \mathrm{~L}$ per day and a level of fat no lower than $3.5 \%$. The milk from each animal was collected in a 5- $\mathrm{L}$ measuring cup and shaken for a few seconds by an automatic stirrer, and three samples of $40 \mathrm{~mL}$ were taken from each of the animals chosen. The chemical composition of the samples was analyzed using an infra-red system (Milko-Scan 133-b, Foss Electric España S.A, Barcelona, Spain).

Fodder consisted of a feed concentrate, made up of corn, wheat bran, barley, soybean meal and barley straw and alfalfa hay. Feeds were offered ad libitum. All the animals had free access to water and mineral block.

\subsection{Extraction of fat}

The fat was obtained after the milk was centrifuged at $1518 \mathrm{~g}$ for $30 \mathrm{~min}$ and was purified in a Soxhlet continuous extraction system (Tecator, Sextec System HT2, 1045 Extraction Unit, Izasa Madrid, Spain), using $30-40^{\circ} \mathrm{C}$ petroleum ether.

\subsection{Analysis of fatty acids}

\subsubsection{Esterification}

$2.5 \mathrm{~mL}$ of sodium methylate $2 \mathrm{~N}$ were added to $0.1 \mathrm{~g}$ of fat and the mixture was reflux heated for $5 \mathrm{~min}$. Next, $3 \mathrm{~mL}$ of a $3 \%$ solution of sulphuric acid in methanol were added and the mix was kept in reflux for $5 \mathrm{~min}$. The methylic esters were extracted with hexane and separated with a saturated solution of sodium chloride.

\subsubsection{Equipment}

The equipment used was a Hewlett Packard 5890 gas chromatograph (Hewlett Packard España, Madrid) with a flame ionization detector (FID) and a capillary column (5\% Fenil Metil Siloxano cross-linking) $30 \mathrm{~m}$ long $\times$ 
$0.25 \mathrm{~mm}$ internal diameter $\times 0.25 \mu \mathrm{m}$ film thickness. Helium was used as a carrier gas with a flow of $1 \mathrm{~mL} / \mathrm{min}$. The integration pack was supplied by Kontron Instruments (Kontron Instruments S.A, Madrid, Spain). The initial temperature of $80^{\circ} \mathrm{C}$ was increased up to $155^{\circ} \mathrm{C}$ at $3{ }^{\circ} \mathrm{C}$ per min, then increased up to $205^{\circ} \mathrm{C}$ at $5^{\circ} \mathrm{C}$ per min and finally to $206^{\circ} \mathrm{C}$ at $0.1^{\circ} \mathrm{C}$ per min. $1 \mu \mathrm{L}$ of the sample was injected.

\subsubsection{Identification}

The identification of the fatty acids was obtained by gas chromatography-mass spectrometry (Hewlett Packard España, Madrid, Spain) programmed at the same analysis conditions as gas chromatography (type of column, temperature and flow). In gas chromatography the quantitative analysis of the samples was obtained by a calibrating line from fatty acid standards (Polyscience Corporation, 2101 Dempster St, Evanston, Il 60201, USA).

\subsection{Statistical analysis}

The results were analyzed applying descriptive statistical analysis (Systat version 5.0, Systat Inc., 1990-92) considering the mean value, standard deviation, maximum and mini- mum value and the confidence interval at $95 \%$ of confidence. Correlations between the different fatty acids were calculated by Pearson coefficients at different significance levels $(P<0.001, P<0.01$ and $P<0.05)$.

\section{RESULTS}

The composition of milk from Murciano-Granadina goats in this study was $4.7 \% \pm 0.7$ fat content; it varied between $3.5 \%$ and $7.4 \%$. The proportion of protein varied between $2.5 \%$ and $3.8 \%$. The proportion of dry extract identified was within a range between $11.5 \%$ and $15.9 \%$, with a mean of $13.1 \%$.

The fatty acids considered noteworthy are those which constituted more than $1 \%$ of the total fatty acids, and these are referred to as the principal fatty acids. The make-up of the principal fatty acids in the milk of Murciano-Granadina goats (table I) is as follows: butyric $(3.0 \%)$, caproic $(6.3 \%)$, caprylic $(2.5 \%)$, capric $(10.4 \%)$. lauric $(5.6 \%)$, myristic $(12.8 \%)$, palmitic $(34.8 \%)$, stearic $(6.8 \%)$, oleic $(13.3 \%)$, linoleic $(3.6 \%)$ and linolenic acid $(0.9 \%)$.

Table I. Percentages of principal fatty acids in Murciano-Granadina goats' milk $(n=39)$.

Tableau I. Pourcentages des principaux acides gras dans le lait de chèvre murciano-granadina $(n=39)$.

\begin{tabular}{lrrrcc}
\hline Acids & Minimum & Maximum & Average & $\begin{array}{c}\text { Standard } \\
\text { deviation }\end{array}$ & $\begin{array}{c}\text { Confidence } \\
\text { interval }\end{array}$ \\
\hline $\mathrm{C}_{4}$ & 1.49 & 4.23 & 2.99 & \pm 0.54 & $2.45-3.55$ \\
$\mathrm{C}_{6}$ & 4.28 & 8.82 & 6.25 & \pm 1.22 & $5.03-7.46$ \\
$\mathrm{C}_{8}$ & 1.70 & 4.12 & 2.52 & \pm 0.41 & $2.11-2.93$ \\
$\mathrm{C}_{10}$ & 8.59 & 12.64 & 10.41 & \pm 0.98 & $9.43-11.39$ \\
$\mathrm{C}_{12}$ & 3.80 & 7.32 & 5.64 & \pm 0.93 & $4.71-6.57$ \\
$\mathrm{C}_{14}$ & 10.70 & 15.26 & 12.81 & \pm 1.16 & $11.66-13.97$ \\
$\mathrm{C}_{16}$ & 27.35 & 40.66 & 34.80 & \pm 3.05 & $31.75-37.85$ \\
$\mathrm{C}_{18}$ & 4.73 & 9.93 & 6.84 & \pm 1.25 & $5.59-8.10$ \\
$\mathrm{C}_{18: 1}$ & 10.34 & 17.08 & 13.26 & \pm 1.58 & $11.68-14.84$ \\
$\mathrm{C}_{18: 2}$ & 2.54 & 4.81 & 3.60 & \pm 0.56 & $3.03-4.24$ \\
$\mathrm{C}_{18: 3}$ & 0.20 & 1.72 & 0.88 & \pm 0.29 & $0.58-1.17$ \\
\hline
\end{tabular}


No significant correlations were found between the quantity of fat present in milk and the values of fatty acids (table II), although Gajdusek et al. in 1994 [4] found a significant correlation between both values. Palmitic acid presents a negative correlation with all the fatty acids and its relationships with oleic acid $(-0.61)$ and capric acid $(-0.52)$ are noteworthy for the higher level of statistical significance $(P<0.001)$. The correlation values between caprylic and capric acid $(0.78)$, oleic and stearic acid (0.52) and oleic and linolenic acid $(0.50)$ were also statistically significant $(P<0.001)$. The same level of statistical significance exists for the negative correlation between caproic acid and myristic acid $(-0.49)$.

\section{DISCUSSION}

The mean fat values are similar to those found in goats of the same breed by Marqués [14] $(4.7 \%)$ and by López et al. [12] $(4.6 \%)$, and lower than those found by Juárez and Martín-Hernández [8] (6.6\%), although the latter are similar to those found in Asiatic breeds by El-Zayat et al. [3] and by Majee et al. [13]. The Saanen and Alpina breeds $[6,18]$ have lower fat percentages $(3.0 \%$ and $2.5 \%$ respectively) than those shown in our results. The protein values obtained $(3.3 \%)$ coincide with the bibliographical references consulted, except the higher value obtained by Majee et al. [13] in the Black Bengal breed. The dry-extract percentages found in the same breed by Juárez and Martín-Hernández [8] and Lafuente et al. [11] (15.7\% and $14.1 \%$ ) are higher than the mean values found in our analysis. Saanen and Alpina breeds present a lower percentage of dry extract $(9.8 \%$ and $10.9 \%)$.

In this study we compare our fatty acid profile in Murciano-Granadina goat milk to several profiles obtained by different authors in goat milk in Spanish and foreign breeds (table III). According to our results the percentage of the following acids: butryric, caprylic, capric, lauric, stearic and linolenic are in the range of the values determined by other authors, mainly in Spanish breeds $[5,10,15]$. The percentage of stearic acid $(6.8 \%)$ is higher than the data found in the study carried out on

Table II. Pearson correlation coefficients between fatty acids and milk fat content.

Tableau II. Coefficient de corrélation de Pearson entre acides gras et quantité de matière grasse du lait.

\begin{tabular}{|c|c|c|c|c|c|c|c|c|c|c|c|}
\hline & $\mathrm{C}_{4}$ & $\mathrm{C}_{6}$ & $\mathrm{C}_{8}$ & $C_{10}$ & $C_{12}$ & $\mathrm{C}_{14}$ & $C_{16}$ & $C_{18}$ & $\mathrm{C}_{18: 1}$ & $C_{18: 2}$ & $\mathrm{C}_{18: 3}$ \\
\hline $\mathrm{C}_{6}$ & n.s. & & & & & & & & & & \\
\hline $\mathrm{C}_{8}$ & n.s. & $0.47^{\mathrm{b}}$ & & & & & & & & & \\
\hline $\mathrm{C}_{10}^{\circ}$ & n.s. & $0.37^{\mathrm{c}}$ & $0.78^{a}$ & & & & & & & & \\
\hline$C_{12}$ & n.s. & n.s. & n.s. & $0.45^{b}$ & & & & & & & \\
\hline $\mathrm{C}_{14}$ & n.s. & $-0.49^{\mathrm{a}}$ & n.s. & n.s. & $0.48^{b}$ & & & & & & \\
\hline $\mathrm{C}_{16}$ & n.s. & n.s. & $-0.43^{b}$ & $-0.52^{\mathrm{a}}$ & $-0.36^{a}$ & n.s. & & & & & \\
\hline $\mathrm{C}_{18}$ & n.s. & n.s. & n.s. & n.s. & $-0.48^{b}$ & $-0.39^{b}$ & $-0.34 c$ & & & & \\
\hline$C_{18: 1}$ & n.s. & n.s. & n.s. & n.s. & n.s. & n.s. & $-0.61^{c}$ & $0.52^{\mathrm{a}}$ & & & \\
\hline $\mathrm{C}_{18: 2}$ & n.s. & n.s. & n.s. & n.s. & n.s. & n.s. & $-0.32^{c}$ & n.s. & n.s. & & \\
\hline$C_{18: 3}$ & n.s. & n.s. & n.s. & n.s. & n.s. & n.s. & $-0.40^{\mathrm{b}}$ & n.s. & $0.50^{\mathrm{a}}$ & n.s. & \\
\hline Fat & n.s. & n.s. & n.s. & n.s. & n.s. & n.s. & n.s. & n.s. & n.s. & n.s. & n.s. \\
\hline
\end{tabular}

${ }^{\text {a }} P<0.001 ;{ }^{b} P<0.01 ;{ }^{\mathrm{c}} P<0.05 ;$ n.s.: non significant. 
Table III. Fatty acid profile in goat milk (\%).

Tableau III. Profil des acides gras du lait de chèvre (\%).

\begin{tabular}{|c|c|c|c|c|c|c|c|c|c|c|c|c|c|c|c|}
\hline \multirow{2}{*}{$\begin{array}{l}\text { Reference } \\
\text { Murciano-Granadina } \\
1996 \text { goat milk, }\end{array}$} & \multirow{2}{*}{$\begin{array}{c}\text { Country } \\
\text { Spain }\end{array}$} & \multicolumn{2}{|c|}{$\begin{array}{l}\text { Number Breed } \\
\text { of animals }\end{array}$} & \multirow{2}{*}{\begin{tabular}{l}
\multicolumn{1}{c}{ Feeding } \\
Maize, wheat bran, \\
barley and soy \\
bean meal
\end{tabular}} & \multirow{2}{*}{$\begin{array}{l}\mathrm{C}_{4} \\
3.0\end{array}$} & \multirow{2}{*}{$\begin{array}{l}\mathrm{C}_{6} \\
6.3\end{array}$} & \multirow{2}{*}{$\begin{array}{l}\mathrm{C}_{8} \\
2.5\end{array}$} & \multirow{2}{*}{$\begin{array}{l}\mathrm{C}_{10} \\
10.4\end{array}$} & \multirow{2}{*}{$\begin{array}{r}\mathrm{C}_{12} \\
5.6\end{array}$} & \multirow{2}{*}{$\begin{array}{r}\mathrm{C}_{14} \\
12.8\end{array}$} & \multirow{2}{*}{$\begin{array}{l}\mathrm{C}_{16} \\
34.8\end{array}$} & \multirow{2}{*}{$\begin{array}{r}\mathrm{C}_{18} \\
6.8\end{array}$} & \multicolumn{3}{|c|}{$\mathrm{C}_{18: 1} \mathrm{C}_{18: 2} \mathrm{C}_{18: 3}$} \\
\hline & & 39 & $\begin{array}{l}\text { Murciano- } \\
\text { Granadina }\end{array}$ & & & & & & & & & & 13.3 & 3.6 & 0.9 \\
\hline Garcia-Olmedo et al. [5] & Spain & 144 & $\begin{array}{l}\text { Spanish } \\
\text { Breeds }\end{array}$ & $\begin{array}{l}\text { Concentrate and } \\
\text { alfalfa hay }\end{array}$ & 2.3 & 2.7 & 3.2 & 11.5 & 5.3 & 10.4 & 24.9 & 9.7 & 21.6 & 1.6 & 1.2 \\
\hline Laencina et al. [10] & Spain & 100 & Murciana & $\begin{array}{l}\text { Wheat bran, } \\
\text { soybean meal }\end{array}$ & 5.8 & 2.5 & 2.9 & 11.5 & 6.6 & 12.0 & 30.9 & 5.8 & 311.7 & 0.9 & - \\
\hline $\begin{array}{l}\text { Martin-Hernandez } \\
\text { et al. [15] }\end{array}$ & Spain & - & $\begin{array}{l}\text { Murciana and } \\
\text { Granadina }\end{array}$ & Maize, barley & 2.2 & 2.6 & 3.2 & 10.6 & 4.8 & 10.3 & 28.4 & 6.3 & 19.7 & 1.8 & 0.3 \\
\hline Klobasa and Senft, [9] & Germany & 5 & - & - & 3.8 & 2.2 & 1.9 & 5.4 & 2.5 & 7.7 & 21.3 & 14.4 & 28.1 & 2.5 & 0.7 \\
\hline $\begin{array}{l}\text { Swaninathan } \\
\text { and Daniel [21] }\end{array}$ & India & - & - & - & 2.6 & 2.3 & 2.7 & 8.4 & 4.5 & 11.1 & 28.9 & 7.8 & 27.8 & 2.6 & - \\
\hline Uusi-Rauva et al. [22] & Finland & - & Finesa & $\begin{array}{l}\text { Soybean meal } \\
\text { and concentrate }\end{array}$ & 4.5 & 3.2 & 3.4 & 9.8 & 4.1 & 8.7 & 21.9 & 8.3 & 20.8 & 3.2 & - \\
\hline Parodi [17] & Australia & - & Saanen & $\begin{array}{l}\text { Wheat bran } \\
\text { and concentrate }\end{array}$ & 4.0 & 3.0 & 3.1 & 8.7 & 3.6 & 9.1 & 23.1 & 12.9 & 24.3 & 2.9 & 1.5 \\
\hline $\begin{array}{l}\text { Morand-Fehr and } \\
\text { Le Jaouen [16] }\end{array}$ & France & 12 & Alpina & $\begin{array}{l}\text { Concentrate and } \\
\text { Lucerne hay }\end{array}$ & 1.6 & 2.0 & 2.4 & 9.7 & 5.0 & 11.6 & 34.0 & 4.5 & 515.1 & 1.9 & 1.2 \\
\hline Cerutti et al. [2] & Italy & 15 & Alpina & $\begin{array}{l}\text { Soy bean meal, } \\
\text { concentrate }\end{array}$ & 3.6 & 3.1 & 3.1 & 9.9 & 3.9 & 10.4 & 27.9 & 12.1 & 19.5 & 1.4 & 0.6 \\
\hline Boros and Stevonkova [1] & Cz. Rep. & 100 & Domestic & Hay and concentrate & 4.5 & 2.4 & 2.4 & 8.3 & 3.2 & 9.0 & 26.1 & 16.7 & 724.9 & 1.1 & 1.1 \\
\hline
\end{tabular}


goats in the Región of Murcia by Laencina et al. [10] $(5.8 \%)$ and lower than that found by García Olmedo et al. [5]. Related to linolenic acid we have found higher values than Martín-Hernández et al. [15] also in goats within the Region of Murcia. On the other hand, the caproic and palmitic acid values are higher than those presented in the bibliography consulted in different national and foreign breeds. The percentage of myristic acid has a similar value compared to other Spanish breeds, which confirms the higher percentage of medium molecular weight fatty acids in Spanish breeds of goat than in foreign breeds [1]. The average value of linoleic acid $(3.6 \%)$ is the highest found in the bibliography consulted, together with the value of Uusi-Rauva et al. [22]. Palmitic acid shows far higher results than in other studies, except compared to the data published by Morand-Fehr and Le Jaouen [16], due to environmental conditions, feeding and handling, which may influence this fatty acid percentage. High energy feeding of the animal studied can produce several modifications in the fatty acid profile, especially in the percentage of palmitic and myristic acid, which agreed with the results published by Morand-Fehr and Le Jaouen [16]. The average value of the oleic acid $(13.3 \%)$ is lower than the results found by the other authors consulted.

The negative correlation between palmitic acid and the rest of the fatty acids was also observed by García Olmedo et al. [5] in a study carried out over 9 months. The correlation figure obtained between oleic acid and stearic acid is highly significant $(P<0.001)$, as expected, since the formation of oleic acid takes place due to the action of desaturase activity of the intestinal epithelium and mammary secretory cell. This results in a conversion of saturated fatty acids to monounsaturated fatty acids, predominantly in the mammarian tissue [7].
In conclusion, it can be said that the average values obtained for caproic and myristic acid are higher than those present in the bibliography either for goats of the Murciano-Granadina breed or for other foreign breeds. Furthermore, the proportion of myristic acid is higher in $85 \%$ of the cases than that found by other authors in Murciano-Granadina goats' milk, a fact which may be explained by the increase in the percentage of short-chain fatty acids derived from the use of genetic improvement. Genetic improvement techniques, mainly based on the function of parameters such as the production and technological suitability of the milk, influence the acid composition of the fat, above all in medium-chain fatty acids [1]. The average value obtained for oleic acid is lower than the percentages found by the other authors consulted, a variation explained by the decisive role of feeding, especially in the quality of fodder, on the proportion of this fatty acid.

\section{ACKNOWLEDGMENTS}

Acknowledgments are due to the Consejería de Agricultura, Medio Ambiente y Agua of the Region of Murcia for providing milk samples and to Mark Christopher Marlowe for translating and correcting the manuscript.

\section{REFERENCES}

[1] Boros V., Stevonkova E., Fatty acid composition of goats' milk fat and variation in fatty acid composition during lactation, Zivocisna Vyroba 35 (1990) 825-831.

[2] Cerutti Ga, Finoli C., Veechio A., Latte di buffala, di pécora e di capra. Composizion e residui cloroorganici, Latte 3 (1978) 310-318.

[3] El-Zayat A.I., Mohamed A.A., Gouda A., Abbas F., Chemical composition and physical properties of goats milk in Suez canal area and Sinai Peninsula, Egypt. J. Food Sci. 12 (1984) 149-154.

[4] Gajdusek S., Jelinek P., Pavel J., Fialova M, Relationships between fatty acids and main components of goats milk, Zivocisna Vyroba 39 (1994) 653-659. 
[5] García Olmedo R., Carballido A., Arnaez Ortiz M., Contribución al estudio de la grasa de leche de cabra: ácidos grasos mayores y sus relacciones, Ann. Bromatol. 31 (1979) 227-270.

[6] Grappin R., Jeunet R., Pillet R., Le Toquin A., Study of goat's milk. I. Content of fat, protein and nitrogenous fractions, Lait 61 (1981) 117-133.

[7] Grummer R.R., Effect of feed on the composition of milk fat, J. Dairy Sci. 74 (1991) 3244-3257.

[8] Juárez M., Martín-Hernández M.C., Caracteristicas de leche y quesos de cabra españoles, Aliment Equip. Tecnol. 4 (1989) 133-137.

[9] Klobasa F., Senft B., Untersuchunger uber das Fellsaurespecktrum im Milchfett von Ziegen, Milchwissenschaft 25 (1970) 453-456.

[10] Laencina J., Moreno M.D., Ocio E., Moreno R., Acidos grasos de la leche de cabra murciana, XIV Jornadas de Estudio, Economía y Técnica de la Producción de Leche de Oveja y Cabra, Zaragoza, Mayo, 1982.

[11] Lafuente A., Urrutia B., Falagán A., Carrizosa J.A., Influencia de la época de partos en las lactaciones de cabras de raza murcianagranadina en Murcia, 43 Reunión Anual de la FEZ, Madrid, 1992.

[12] López M.B., Botet M.J., Hellín P., Luna A., Laencina J., Effect of thermal treatment on goat milk clotting time, Milchwissenschaft 50 (1995) 126-129.

[13] Majee J., Bandyopadhyay A.K., Ghatak P.K., Physico-chemical properties of Black Bengal goat milk, J. Dairy Foods Home Sci. 13 (1994) 119-122.

[14] Marqués F., Algunos parámetros lecheros de la agrupación murciana-granadina, Simposium sobre la Cabra en los Países Mediterráneos, Málaga, 1977, pp. 261-361.
[15] Martín-Hernández C., Juárez M., Ramos M., Martín-Alvarez P.J., Composición de la leche de cabra Murciana y Granadina, An. Bromatol. 10 (1988) 237-248.

[16] Morand-Fehr P., Le Jaouen J.C., Influence de divers facteurs alimentaires sur la composition du lait et les caractéristiques du fromage de chèvre, Simposium sobre la Cabra en los Países Mediterráneos, Málaga, 1977, pp. 146-155.

[17] Parodi W., Detection of synthesis and adulterated butterfat. 3 . Triglyceride fatty acids analysis, Aust. J. Dairy Technol. 26 (1971) $155-159$.

[18] Pirisi A., Colin O., Laurent F., Scher J., Parmentier M., Comparison of milk composition, cheesemaking properties and textural characteristics of the cheese from two groups of goats with a high or low rate of $\alpha_{\mathrm{s} 1}$-casein synthesis, Int. Dairy J. 4 (1994) 329-345.

[19] Ramos M., Juárez M., Chromatographic electrophoretic and immunological methods for detecting mixtures of milks from different species, Bull. Int. Dairy Fed. 202 (1986) 175-187.

[20] Sauvant D., Morand-Fehr P., Rudolphe F., Tomassone R., Delage J., Etude des interrelations entre les critères de production et de composition lipidique du lait de chèvre par deux méthodes d'analyse factorielle, Ann. Biol. Anim. Biochim. Biophys. 13 (1973) 107-111.

[21] Swaminathan M., Daniel V.A., The chemical composition and nutritive value of goat's milk and its products, Indian J. Nutr. Diet. 7 (1970) 252-266.

[22] Uusi-Rauva E., Sirpa A., Antila M., Die Zusammensetzung der finnischen Ziegenmilch, Suom. Kem. B 43 (1970) 178-182. 